\title{
Total Quality Management Practices and Supply Chain Performance among Manufacturing and Allied Companies Listed at Nairobi Securities Exchange, Kenya
}

\author{
Karumba Michael Wachira, David Kiarie Mburu, and Richard Kiai
}

\section{ABSTRACT}

The state of organizational supply chain performance has attracted great attention to organizations in their endeavour to create superior structures and systems to guarantee shareholder wealth maximization. An efficient and effective supply chain framework will reduce wastages and optimally grasp opportunities in the best interest of investors. Poor supply chain performance represents over $60 \%$ of the challenges facing the global and local manufacturing industry and remain a major hurdle in securing superior firm performance. The study assessed the influence of TQM on supply chain performance for manufacturing and Allied firms listed at NSE, Kenya. Specifically, the study sought to assess the effect of strategic quality planning, supplier relations management, management commitment and customer focus on Supply Chain Performance. The guiding theories included Deming's Quality Improvement Theory, Goldratt's Theory of Constraints and Supply Chain Operations Reference (SCOR) Model. The descriptive survey research approach was used to carry out the study. A semi structured questionnaire helped in primary data collection. On the other hand, secondary data was reviewed using a document review guide. Data collection covered the period between 2013/2014 and 2017/2018 financial years. Quantitative and qualitative analysis techniques were employed. Quantitative techniques were included descriptive and inferential statistics. In particular, the multiple regression analysis aided in testing the hypotheses. From the regression analysis results, all the null hypotheses were rejected as all the TQM variables were found to influence supply chain performance. The $p$-value for strategic quality planning $(p=0.014)$ is less than 0.05 level of significance which informs a conclusion that strategic quality planning has a positive effect on supply chain performance. The p- value for supplier relations management $(p=0.005)$ is less than 0.05 level of significance which informs a conclusion that supplier relations management has a positive effect on supply chain performance. The $p$ value for customer focus $(p=0.017)$ is less than 0.05 level of significance which informs a conclusion that customer focus has a positive effect on supply chain performance. The $p$ value for management commitment $(p=0.004)$ is less than 0.05 level of significance which informs a conclusion that management commitment has a positive effect on supply chain performance. The Coefficient of Determination ( $R$ Square) stood at 0765. This meant that $76.5 \%$ of variation in supply chain performance was influenced by variation in the independent variable that is total quality management practices and its constituent variables: Strategic Quality Planning, Supplier Relations Management, Customer Focus and Management Commitment. To that effect, only $23.50 \%$ of variation in supply chain performance was explained by other factors not included in the model. Although supplier relations management was deeply entrenched, the study recommends further improvement of the framework of supplier engagement to quality initiatives which was found to be only moderately practiced. The study recommends further improvement of customer relations management function to ensure timely and effective handling of customers concerns and feedback to suppliers. The study recommends regular market research to effectively monitor and respond to new market needs as they arise.

Keywords: Customer Focus, Management Commitment, Supplier Relations Management, Strategic, Quality Planning, Total Quality Management.
Submitted : December 01, 2021

Published : February 22, 2022

ISSN: 2507-1076

DOI: $10.24018 /$ ejbmr.2022.7.1.1188

Karumba Michael Wachira

Msc Supply Chain Management, Dedan Kimathi University of Technology, Kenya.

David Kiarie Mburu*

Dedan Kimathi University of Technology,

Kenya.

(e-mail: dkmburu2@gmail.com)

Richard Kiai

Karatina University, Kenya.

*Corresponding Author 


\section{INTRODUCTION}

Globally, the International Monetary Fund appraises the manufacturing sector as a significant player to global economic growth and development accounting for more than sixteen percent of global Gross Domestic Product (GDP). Consequently, local economies have continued to launch sector specific programs to accelerate the growth of the manufacturing sector. Nonetheless, the Covid-19 pandemic has seriously affected the global manufacturing sector and has occasioned closure of many manufacturing concerns around the world. The United Nations Conference on Trade and Development (UNCTAD, 2020) indicates that the Covid-19 pandemic could have caused between 5 to $15 \%$ shrinking of the global manufacturing industry. The global manufacturing supply-chain has not been spared either with losses being witnessed as a result of the initial COVID-19 lockdowns.

Nonetheless, for Africa as a region, the manufacturing sector has continued to lag behind even before the onset of the Covid 19 pandemic. In 2017, manufacturing's share of sub-Saharan Africa's total GDP was just under 10\%. In terms of two other indicators of industrial development manufacturing value added (MVA) and manufacturing exports - Africa lags far behind the rest of the world, even among developing countries (UNCTAD, 2017). The UN Economic Commission for Africa (ECA, 2015) indicated that the contribution of Africa's manufacturing sector to the continent's gross domestic product actually declined from $12 \%$ in 1980 to $11 \%$ in 2013 , where it has remained stagnant over the past few years.

Locally, the Kenya National Bureau of Statistics (2018) observes that the Kenyan manufacturing growth has, like the regional situation, been stagnant. The contribution to the manufacturing sector to the economy in Kenya has stagnated at around below $10 \%$ of the gross domestic product (GDP). For the year 2017, the contribution of the manufacturing sector to GDP stood at $8.4 \%$. There is renewed interest in the manufacturing sector through the Big 4 Agenda which seeks to increase the GDP contribution of the sector to $15 \%$ by 2022 .

Supply chain performance has received keen interest in corporate circles as organisations pursue ways to build their competitive advantage and deliver maximised shareholder's wealth (Otto \& Kotzab, 2003). According to Christopher (2016), supply chain performance encompasses the extended supply chain's activities in meeting the tastes and interests of customers such as product availability, deliverables, attributes, use and on-time delivery. The performance of the supply chain therefore concerns its abilities to create competitive edge by reducing unit costs, waste, and time in addition to ensuring a flexible response to issues that emerge (Harrison \& Van Hoek, 2008).

Supply chain management has evolved as a critical pillar of overall organisational success as it seeks to manage the flow of products from suppliers to consumers (Christopher, 2016). The supply chain encompasses a range of associated processes which need to be properly monitored and controlled as the organisation seeks to deliver products to end users while enhancing their competitive advantage (Hausman, 2004). According to Hugos (2011), the principal concentration of supply chain management is on costs and quality of materials in addition to efficient delivery which is best achieved through structured framework of quality management and control. Supply chain management focuses on meeting the interests of various organisational stakeholders. Discussions continue to flow on the relationship between supply chain performance and total quality management in organisation (Otto \& Kotzab, 2003).

Integrating quality control and assurance into the supply chain has therefore emerged as a prime focus of modern day organisations. In particular total quality management is being embraced a popular tool to deliver superior supply chain performance (Forker, Mendez \& Hershauer, 1997). The concept of TQM is built on the ladder of overall quality measures for an organisation including, quality development, control, and assurance (Chang, 2009).

\section{A. Supply Chain Performance}

According to Gunasekaran, Patel and McGaughey (2004), supply chain performance entails the level to which the supply chain effectively and efficiently meets the end customer's needs through product availability, responsiveness, delivering desired variety, utilising capacity, and on-time delivery of those offerings. The supply chain performance measurement involves an appraisal on the overall operation level, the node enterprise units within the supply chain, and the cooperation relationship between the node units (Hervani, Helms, \& Sarkis, 2005).

As opined by Gunasekaran et al. (2004), a wholesome approach to supply chain performance measurement encompasses embracing a wide range of metrics at all levels which include strategic, tactical, and operational levels. Strategic level metrics focus on the level of adherence to organisational supply chain management goals and serve to stimulate top management decisions and informing the adoption or modification of broad based policies. The tactical level metrics are concerned with resource allocation and assessment of performance against set targets. The operational metrics apply to day to day activities of a firm (Wagner \& Bode, 2008).

According to Cai, Liu, Xiao, and Liu (2009), the most effective method to achieve KPI goals for the supply chain must connect planning, and execution, and assess the extent to which steps are built for realization of performance objectives into routine daily work. To this end, supply chain planning, supplier selection and supplier integration serve as key indicators (Cagnazzo, Taticchi, \& Brun, 2010). The current study embraced a wide range of measures as contained in the Supply Chain Operations Reference (SCOR) Model. These indicators included supply chain reliability, supply chain responsiveness, supply chain flexibility, supply chain costs and supply chain asset management.

\section{B. Total Quality Management Practices}

Goetsch and Davis (2014) presents TQM as an approach that aims at enhancing quality and organisational performance by offering products that quench the tastes and prospects of clients. To fulfil the goals of TQM, it is critical that all quality-related functions and processes are integrated. Total quality management focuses on managing quality standards and guidelines including quality design 
and development, quality improvement, quality assurance as well as quality control and maintenance (Dale, 2015).

According to José (2005), TQM aims at doing things the right way, right from the first time, over and over again. Through application of TQM principles, the organization is able to save the time required to correct poor work or faulty products and service implementations. TQM can be established separately for an organization or organisations could still adopt a set of internationally recognised standards to follow such as the International Organization for Standardization (ISO) standards. Vanagas and Žirgutiene (2015) present TQM as the control of initiatives and processes with a view to deliver quality products to organisational clients. Hashmi (2007) reviews total quality management principles that are instrumental in achieving quality goals of firms. These include, executive management or top management support, training, customer focus, decision making, methodology and tools, supplier relations management, strategic planning, continuous improvement, company culture, employee involvement, and constant communication and feedback.

As Bonstingl (1992) opines, executive management or top management support plays a critical role to the realisation of TQM goals through nurturing an environment that ensures the success of the firm. The organisational workforce needs regular training on the methods and concepts of quality to improve their productivity (Kelly, 2013). Communication and feedback make stakeholders feel appreciated and motivates them to contribute to quality objectives. Supplier relations management is essential in supporting effective supplier selection and integration (Dahlgaard et al., 2008). Strategic planning needs to be adopted at all stages of the supply chain in order to work out the right approach. The supply chain strategic planning practices include demand management process, strategic distribution planning and strategic warehouse planning and design. Customer focus concerns quality enhancements in products and services to boost customer satisfaction (Mohideen \& Vijayavel, 2014).

Crainer and Dearlove (2004) asserts that decision making needs to be objective and based on measurements and evidence so as to reduce failures or errors. Firms should also employ, the appropriate methodology and tools to make sure that non-conformance cases are recognised, measured, and responded to quickly and consistently (Yong \& Wilkinson, 2001). Through pursuit of continuous improvement goals, the organisation is able to work towards improving manufacturing and quality procedures (Evans \& Dean, 2003). It is important that the organisation retains an appropriate culture that emphasises on development of employees' ability to work together to improve quality (Farooq, Akhtar, Ullah, \& Memon, 2007). Lastly, it is imperative to involve employees at all levels which inspires them to be pro-active in recognising and addressing quality related problems (José, 2005).

\section{Statement OF THE PRoblem}

Ngui (2008) singles out the manufacturing sector as the most potential areas as contributors to growth, employment and wealth creation as envisioned in Vision 2030.
Nonetheless, as reported by KNBS (2017), the manufacturing sector has been struggling to achieve the ten percent contribution target to GDP as envisioned Kenya's vision 2030. Furthermore, the manufacturing sector has been registering the slowest growth in the recent past (KAM, 2017). Failure to meet this projection negatively impacts on the national economic plans. Njoroge (2014) unveils a poor state of manufacturing supply chain performance especially as relates to costs, asset management and reliability. Poor supply chain performance represents over $60 \%$ of the challenges facing the global and local manufacturing industry and remain a major hurdle in securing superior firm performance (Stadtler, 2005). This condition is exemplified by Garetti and Taisch (2012) who indicate that inability to deliver superior supply chain performance continues to hurt other aspects of the manufacturing concerns.

Katua (2014) analyzed supply chain performance among players in the manufacturing sector in Kenya and reported shortcomings in meeting supply chain objectives. This is also reported by Oketch, Chirchir and Kinyua (2014) who evaluated supply chain performance among Kenyan pharmaceutical manufacturers. Talavera (2010) highlighted that the problem of poor supply chain performance was characteristic of the global manufacturing industry. The declining performance of the sector suggests poor internal systems in the individual players worth addressing. Total quality management in the supply chain has been identified as one of the practices that contribute to improvement in performance of the supply chain and the entire organisational system.

The adoption of TQM initiatives serves to reduce costs, enhance customer focus and satisfaction as well as build innovative and reliable processes (Cai, Liu, Xiao, \& Liu, 2009). The benefits of investing in the quality of the supply chain far much outweigh the costs. Thus, the study is structured in a manner that expands the wealth of knowledge on the subjects of TQM practices and Supply Chain Performance.

\section{SPECIFIC OBJECTIVES}

i. To establish the influence of strategic quality planning on supply chain performance for manufacturing firms listed at NSE, Kenya.

ii. To evaluate the influence of supplier relations management on supply chain performance for manufacturing firms listed at NSE, Kenya.

iii. To assess the influence of customer focus on supply chain performance for manufacturing firms listed at NSE, Kenya.

iv. To understand the influence of management commitment on supply chain performance for manufacturing firms listed at NSE, Kenya.

\section{RESEARCH HYPOTHESIS}

H01: Strategic Quality Planning does not show significant influence on supply chain performance for manufacturing firms listed at NSE, Kenya.

Ho2: There exists no significant impact of supplier 
relations management on supply chain performance for manufacturing firms listed at Nairobi NSE, Kenya.

H03: Customer focus has no noteworthy impact on supply chain performance for manufacturing firms listed at NSE, Kenya.

H04: Management commitment does not exhibit a noteworthy impact on supply chain performance for manufacturing firms listed at NSE, Kenya.

\section{THEORETICAL FRAMEWORK}

The theoretical framework entails a summary of theories guiding the study. The guiding theories include Deming's Quality Improvement Theory, Goldratt's Theory of Constraints and Supply Chain Operations Reference (SCOR) Model. The theories present the link between the variables and the theory.

\section{A. Deming's Quality Improvement Theory}

Deming (1986) pioneered the quality improvement theory. The theory holds that executive level in an organization ensures that quality management is well executed. Hence the executive level function is critical, strategic initiatives stay ineffective and may not have any important outcome on either the supply chain performance or organisational success (Anderson, Rungtusanatham, \& Schroeder, 1994). Management commitment, the theory suggests, influences not just the success of TQM initiatives but also contributes to enhanced supply chain performance. The theory argues that the management is critical factor to the success of an organization.

The theory outlines a good plan to firms in order to yield good quality control measures for effective managerial techniques. Evans and Lindsay (2002) states that the management's behaviour improves corporate attitude and also guarantee the going concern of a firm. The theory upheld the Plan Do Check Act (PDCA) cycle as an orderly method to problem-solving. Proponents argued that the model serves to guarantee continuous improvement in the organization and ultimately superb performance of the supply chain. Strategic quality planning is given key emphasis as an important contributor to supply chain performance (Goetsch \& Davis, 2006). Hence the theoretical orientations help in aligning the firm's offering to customer expectations.

\section{B. Goldratt's Theory of Constraints}

Goldratt (1990) initiated the theory as a helpful tool in organisational management. Boyd and Gupta (2004) describe the model as a management paradigm that considers systems as being restricted in achieving more organization goals by some underlying constraints. The theoretical model seeks to identify the key restraining factor (bottleneck) which hinders in achieving an organization goal. This is followed by objective identification of a plan to improve the constraint until the factor is eliminated. In the context of the study, the model would help identify the quality concerns and device ways of improving the supply chain performance (Gupta, Bhardwaj \& Kanda, 2010). In order to achieve organisational goals, necessary conditions need to be met first. As the organisation grapples with constrained level of resources, it is imperative to integrate an efficient framework of supply chain quality planning, customer focus, supplier relations management and management commitment to ensure that the organisational supply chain goals are met.

Gupta et al. (2010) assert that failure to forecast into the future may negatively impact on organizational goals as a result of unidentified constraints. Thus, integration of quality planning into the supply chain would provide solutions to some shortcomings brought about by supply chain constraints. Supply chain quality planning ensures that customers have the right products, at the right time, in the right form and standards. This helps in achieving the objects of supply chain management as indicated in the supply chain operations reference tool. It helps organisations appreciate and meet the growing needs of customers and thus overcome stock out costs; prolonged lead time, reduced holding costs leading to enhanced supply chain performance (Tulasi \& Rao, 2012). On the same note, building strong bonds with suppliers would also help in overcoming some constraints to this regard. The applicability of this theory is built on the fact that it enlightens the management of an organization on the need to prepare for the future through supply chain quality planning, supplier relations management, management commitment and customer focus as key variables of interest to the study.

\section{Supply Chain Operations Reference (SCOR) Model}

According to Poluha (2007), the SCOR model is a process reference model useful in measuring the performance of the supply chain process and network. The SCOR tool is advanced and recommended by the Supply Chain Council as the cross-industry, standard diagnostic tool for supply chain management (Stephens, 2001). According to $\mathrm{Li}, \mathrm{Su}$ and Chen (2011), the SCOR framework model aids users in addressing, improving, and collaborating supply chain management practices among stakeholders who include but not limited to customers and suppliers. The SCOR Model aids inter and intra supply chain cooperation and horizontal process integration (Estampe, Lamouri, Paris \& Brahim-Djelloul, 2013).

As Poluha (2007) posits, the performance measurements pillar of the SCOR Model further presents useful indicators in the measurement of supply chain performance. The SCOR metrics are used in conjunction with a set of performance attributes to ensure an all-round assessment. The attributes include costs, asset management, reliability, agility and responsiveness (Supply Chain Council, 2008). The theory is helpful in evaluating the influence of management commitment, supplier relations management, strategic quality planning and customer focus on supply chain performance.

Criticism of the SCOR model indicate that the model is too focused on operational measurements and fails to provide a framework in support of long-term strategies. Critics have cited this weakness indicating that the SCOR Model mainly focuses on processes and efficiency but not on strategy (Fekpe et al., 2015). Nonetheless, Poluha (2007) cites key strengths in applying the SCOR Model as it simplifies and accelerates the design of supply chain models. 


\section{EMPIRICAL LITERATURE REVIEW}

This entailed an in-depth review of past research regarding the key variables of the study with the aim of establishing gaps in the area of the study.

\section{A. Total Quality Management and Supply Chain Performance}

Vanichchinchai and Igel (2011) studied TQM and supply chain performance. The study covered the automotive industry in Thailand. The study used descriptive survey research method. Specifically, the study targeted two large first-tier automotive suppliers in Thailand. Path analysis was employed in testing the hypothesized model of the study. Study findings indicated that total quality management practices yield a positive effect on supply chain performance. As most past studies are done in other countries, contextual gaps are established.

Fouad, Hamed and Abdulwahhab (2015) analysed TQM, supply chain management and Oil Pipelines Company's performance in Baghdad, Iraq. The study utilised path analysis to demonstrate that total quality management and supply chain management positively influenced organization performance. Studies should now extend the assessment to cover the effect TQM on performance of the supply chain besides the overall firm performance.

Masindet and Ogollah (2014) examined TQM and supply chain performance. The research concluded management commitment positively enhanced supply chain performance. Methodological gaps were presented hence use of inferential statistics too in the analysis for more justifiable generalisations on the population should be done.

\section{B. Strategic Quality Planning and Supply Chain Performance}

Tan, Ng, Phuah, Phuah and Tan (2014) studied TQM practices supply chain performance. The study targeted logistics companies in Malaysia. From the results, strategic quality planning was found to be significantly and positively associated to Supply Chain Management performance. Empirical gaps are identified on necessity to embrace more TQM variables such as management commitment and supplier relations management in the analysis.

Kamau et al. (2015) assessed supply chain quality planning and performance of water bottling firms in Nairobi County. A cross sectional survey and descriptive research designs were adopted. The study identified demand management, distribution management, warehouse planning and strategic sourcing as key dimensions of strategic quality planning in the supply chain. The study results demonstrated that supply chain strategic quality planning has an effect on supply chain performance.

Baraza (2015) examined strategic quality planning and performance of mobile communications service providers. Strategic quality planning was taken up as one of the variables of interest in the assessment. Three mobile communications service providers namely Safaricom Limited, Telkom Kenya (Orange Kenya) and Airtel Kenya were targeted. Study results demonstrated that strategic quality planning impacted on firm performance. Studies should now shift attention to supply chain performance and not just firm performance.

\section{Supplier Relations Management and Supply Chain} Performance

Kitheka (2015) studied supplier quality management, with a consideration on how it impacted on performance of supermarkets in Kakamega Town, Kenya. Descriptive analysis method was utilised with results indicating that various dimension of supplier relations management such as supplier audits, supplier development, and competitive selection influence performance. Studies should assess more TQM practices and consider analysing supply chain performance as influenced by those quality practices.

Rajab (2015) investigated TQM and performance of large-scale manufacturing companies' supply chain in Kenya. Supplier partnering as a facet of supplier relations management was identified as one of the quality management systems implemented. Results further showed that supplier partnering positively impacted on performance of the supply chain. Conceptual gaps are as the concept of supplier relations management need to be expanded in the analysis.

Talib, Rahman and Qureshi (2011) studied TQM and supply chain performance. Specifically, the study sough to determine and highlight key TQM and SCM practices adopted by firms and define their relationships. The methodology adopted involved an extensive literature review principally from published research papers. The results revealed that supplier relations management strongly and significantly influences supply chain performance. There is a gap as the study fell shied off from an empirical investigation to allow validation and generalization of results as the study relied solely on literature review of previously published studies.

\section{Customer Focus and Supply Chain Performance}

The study by Tan et al. (2014) on TQM and SCM practices revealed that customer focus was positive influenced related to supply chain performance. Sik Jeong and Hong (2017) studied customer orientation and supply chain performance outcomes. The approach adopted reviews past literature on customer orientation and supply chain network performance outcomes to arrive at conclusions. The results support the hypothesis that customer orientation influences supply chain performance outcomes.

Kitheka (2015) studied supplier quality management, with a consideration on how it impacted on performance of supermarkets in Kakamega Town, Kenya. Descriptive analysis method was utilized with results indicating that TQM has performance enhancing effects. Rajab (2015) investigated TQM and performance of large scale manufacturing companies' supply chain in Kenya. TQM was found to positively influence performance.

Talib, Rahman and Qureshi (2011) studied TQM and supply chain performance. Specifically, the study sough to determine and highlight key TQM and SCM practices adopted by firms and define their relationships. The methodology adopted involved an extensive literature review principally from published research papers. The results revealed that TQM strongly and significantly influences supply chain performance. There is a gap as the study fell shied off from an empirical investigation to allow validation and generalization of results as the study relied 
solely on literature review of previously published studies.

The study by Masindet and Ogollah (2014) indicated that customer focus and customer orientation positively contributed to supply chain performance. Current studies should incorporate more TQM variables including Supplier Relations Management and Strategic Supply Chain Planning. Methodological gaps are also highlighted on the need to use inferential statistics too in the analysis for more justifiable generalisations on the population.

\section{E. Conceptual Framework}

A conceptual framework is an analytical tool applied in research development to get a comprehensive understanding of a phenomenon and interrelationships among the variables involved (Kothari, 2011). The outline aids in hypothesizing the relationships between the variables to be tested in the analysis to determine the effect of TQM practices on supply chain performance.

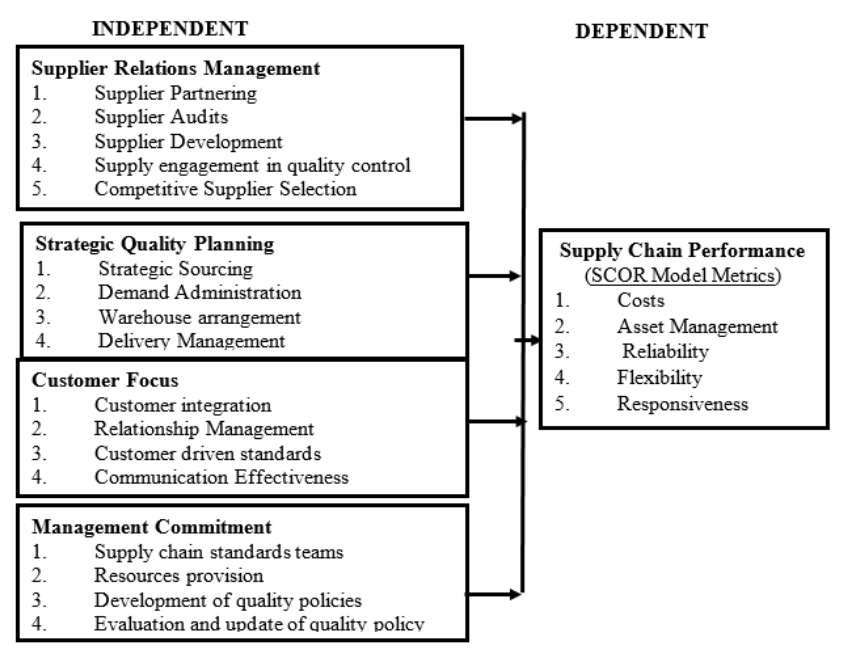

Fig. 1. Conceptual Framework.

\section{RESEARCH Methodology}

The current research applied positivism philosophy so as to justify the theories or explanations in the study. The philosophy recognises variables in the study and links them to hypotheses.

A descriptive survey approach was preferred for the study since it explores and answer the questions what? Where? how? of an underlying condition or phenomena (Kothari, 2011). The target population are 9 manufacturing firms listed at NSE as of April 2019 where Procurement Heads, CEOs, Accountants, Quality Assurance Heads, and Customer Relationship Managers were identified as the target respondents amounting to 45(one per company). The consideration of listed manufacturers is justified by the fact that the companies have in the recent past recorded declining supply chain and overall organisational performance. Census was used where all the 45 target population was used as sample size.

Primary and secondary data was used. A questionnaire was preferred for collection of primary data for the potential benefits such as effectiveness and efficiency in obtaining relevant data (Kothari, 2011). Questionnaires were distributed to the target respondents to obtain primary data. Secondary data was obtained from published reports of the manufacturing firms listed at NSE. Reports concerning the manufacturing companies was also availed by authorities such as Capital Markets Authority, Nairobi Stock Exchange.

The study also carried out preliminary diagnostic tests meant to ascertain that the data sets met the general assumptions for conducting the regression analysis, a key inferential tool for the current study. The main analysis involved descriptive analysis and inferential analysis. Descriptive analysis helped in describing in detail, the state of the total quality management practices and supply chain performance. On the other hand, inferential analysis helped in deducing inferences or generalisations on the entire population.

In particular, the multiple linear regression was key in establishing the strength and direction of effect of total quality management practices on supply chain performance and hence provided a framework for effectively testing the research hypothesis. The hypothesis was tested at $95 \%$ confidence levels. As such, a 5\% level of significance guided whether the effect of each variable on supply chain performance was significant. To be precise, if the $\mathrm{p}-$ values were found to be greater than 0.05 level of significance, the null hypothesis would not be rejected. As such, a conclusion would be made that the variable does not have a statistically significant effect on supply chain performance. Conversely, if the p-values were found to be less than 0.05 , this would mean that the null hypothesis would be rejected, and a conclusion made that the variable in question is a statistically significant determinant of supply chain performance.

\section{Empirical Model}

$$
Y=\beta_{0}+\beta_{1} X_{1}+\beta_{2} X_{2}+\beta_{3} X_{3}+\beta_{4} X_{4}+\varepsilon
$$

where

$\mathrm{Y}=$ Supply Chain Performance;

$\beta_{0}=$ Intercept;

$\mathrm{X}_{1}=$ Strategic Quality Planning;

$\mathrm{X}_{2=}$ Supplier Relations Management;

$3=$ Customer Focus;

$\mathrm{X}_{4}=$ Management Commitment;

$\beta_{1}$ to $\beta_{4}=$ Regression Factors or Gradients;

$\varepsilon=$ error term.

Data was presented in form of tables and figures.

\section{RESEARCH FINDINGS AND DISCUSSIONS}

The study targeted a total of 45 respondents and the questionnaires were delivered in all the 9 Manufacturing companies listed at Nairobi Securities Exchange. The response rate was $80.00 \%$ as only 36 out of the 45 questionnaires were successfully returned. Mugenda and Mugenda (2003) argues that a response rate of 50\% is just adequate, $60 \%$ good and above $70 \%$ very good for statistical purposes.

\section{A. Supply Chain Performance}

This part provides descriptive statistics regarding supply chain performance among manufacturing firms listed at NSE, Kenya. Table I provides details on supply chain costs. 
TABLE I: SUPPLY CHAIN COSTS

\begin{tabular}{cccccc}
\multicolumn{7}{c}{ TABLE I: SUPPLY CHAIN COSTS } \\
\hline & $\mathrm{N}$ & Min & Max & Mean & Std. Dev. \\
\hline Supply Chain & 36 & 3.73 & 5.32 & 4.7684 & 0.61974 \\
Management Cost & 36 & 45.0 & 63.0 & 53.7684 & 6.91976 \\
Cost of Goods Sold & 36 & & & \\
Valid N (listwise) & 36 & & & & \\
\hline
\end{tabular}

The supply chain costs include the supply chain management costs and the cost of goods sold. On average, the supply chain management costs for the manufacturing companies stood at approximately between $4 \%$ and 5\%, averaging at $5 \%$. The cost of goods sold on the other hand averaged at $58 \%$ with the range being between $45 \%$ and $63 \%$.

TABLE II: SUPPLY CHAIN RELIABILITY

\begin{tabular}{cccccc}
\multicolumn{6}{c}{ TABLE II: SUPPLY CHAIN RELIABILITY } \\
\hline & $\mathrm{N}$ & Min & Max & Mean & Std. Dev \\
\hline $\begin{array}{c}\text { Cash-to-Cash cycle } \\
\text { time }\end{array}$ & 36 & $\begin{array}{c}11.5 \\
1\end{array}$ & 19.08 & 14.0001 & 2.80177 \\
$\begin{array}{c}\text { Return on Supply } \\
\text { Chain Fixed Assets }\end{array}$ & 36 & 5.34 & 8.01 & 6.2506 & 0.90015 \\
$\begin{array}{c}\text { Return on Working } \\
\text { Capital }\end{array}$ & 36 & 4.00 & 5.08 & 3.3527 & 0.25745 \\
Valid N (listwise) & 36 & & & & \\
\hline
\end{tabular}

The average cash to cash cycle time for the manufacturing entities was two weeks. This demonstrates that the firms were able to control the time that cash was tied up in the main cash producing and cash consuming areas: receivables, payables, and inventory. The Return on Supply Chain Fixed Assets and Return on Working Capital stood at an average of $6 \%$ and $3 \%$, respectively.

\begin{tabular}{|c|c|c|c|c|c|}
\hline & $\mathrm{N}$ & Min & Max & Mean & Std. Dev. \\
\hline $\begin{array}{l}\text { Order Fulfilment } \\
\text { Cycle Time }\end{array}$ & 36 & 12.7 & 18.8 & $\begin{array}{c}16.768 \\
4\end{array}$ & 2.26546 \\
\hline Valid N (listwise) & 36 & & & & \\
\hline
\end{tabular}

The order fulfilment cycle time stood at an average of slightly above two weeks or 16 days to be precise. This demonstrates that the manufacturing firms are able to effectively control timelines relating to sourcing, production and delivery.

\begin{tabular}{cccccc}
\multicolumn{5}{c}{ TABLE IV: SUPPLY CHAIN ReSPONSIVENESS } \\
& N & Min & Max & Mean & Std. Dev. \\
\hline $\begin{array}{c}\text { Upside Supply } \\
\text { Chain }\end{array}$ & 36 & 19.4 & 28.3 & 21.0001 & 1.68219 \\
$\begin{array}{c}\text { Flexibility } \\
\text { Valid N } \\
\text { (listwise) }\end{array}$ & 36 & & & & \\
\hline
\end{tabular}

The upside supply chain flexibility scored an average of 21 days. Thus, the supply chain would take an average of three weeks to respond to an unplanned $20 \%$ increase in demand without service or cost penalties.

\section{B. Supplier Relations Management}

This part provides descriptive statistics regarding supplier relations management for the manufacturing firms listed at NSE. Table V provides a summary of the results.

The average of means (3.977) shows that supplier relations management was well implemented as a total quality management practice for the manufacturing firms. The low average of standard deviation (1.314) also affirms this state of affairs indicating that the observations were held close to the mean. The companies ensured that there was good relationship with suppliers by developing structures and partnering to ensure quality controls and enhancement of products. The companies had also largely established supplier audit systems to ensure compliance with set quality standards. The companies had also largely entrenched well spelt guidelines to ensure competitive supplier selection on ability to deliver quality. However, the company engaged suppliers to a moderate level in formulation of quality control initiatives

TABLE V: SUPPLIER RELATIONS MANAGEMENT

\begin{tabular}{|c|c|c|c|}
\hline & $\mathrm{N}$ & Mean & Std. Dev. \\
\hline $\begin{array}{l}\text { The organization has well put structures } \\
\text { to manage relations with her suppliers }\end{array}$ & 36 & 4.0000 & 1.26491 \\
\hline $\begin{array}{l}\text { The company regularly partners with } \\
\text { suppliers to ensure quality control, } \\
\text { compliance and enhancement of products }\end{array}$ & 36 & 4.0000 & 1.26491 \\
\hline $\begin{array}{l}\text { The company has a well-established } \\
\text { supplier audit system to ensure } \\
\text { compliance with set quality standards }\end{array}$ & 36 & 4.0833 & 1.20416 \\
\hline $\begin{array}{l}\text { The company has a well formulated } \\
\text { policy and action plan on supplier } \\
\text { development to regularly enhance quality }\end{array}$ & 36 & 4.1111 & 1.40972 \\
\hline $\begin{array}{l}\text { The company engages suppliers in the } \\
\text { formulation and execution of quality } \\
\text { control initiatives }\end{array}$ & 36 & 3.6389 & 1.37639 \\
\hline $\begin{array}{l}\text { The company has a well spelt out } \\
\text { guideline to ensure competitive supplier } \\
\text { selection on ability to deliver quality }\end{array}$ & 36 & 4.0278 & 1.36248 \\
\hline Average & & 3.97685 & 1.31376 \\
\hline
\end{tabular}

\section{Strategic Quality Planning}

The descriptive statistics (means and standard deviation) for application of strategic quality planning is provided in Table VI.

\section{TABLE VI: STRATEGIC QUALITY PLANNING}

\begin{tabular}{|c|c|c|c|}
\hline & $\mathrm{N}$ & Mean & Std. Dev. \\
\hline $\begin{array}{l}\text { The company engages in strategic } \\
\text { sourcing to ensure timely delivery of } \\
\text { quality products }\end{array}$ & 36 & 3.8056 & 1.26083 \\
\hline $\begin{array}{l}\text { The company has a well formulated and } \\
\text { effective demand management system }\end{array}$ & 36 & 4.0278 & 1.31987 \\
\hline $\begin{array}{l}\text { The company has a put in place an } \\
\text { effective distribution management system }\end{array}$ & 36 & 3.9444 & 1.43317 \\
\hline $\begin{array}{l}\text { The company has a well-executed } \\
\text { warehouse planning system to ensure } \\
\text { quality storage of products }\end{array}$ & 36 & 4.1111 & 1.30445 \\
\hline Average & & 3.97222 & 1.32958 \\
\hline
\end{tabular}

The average for various factors assessed (3.972) shows that strategic quality planning was executed to great extent by the manufacturing entities. This was further shown by the low standard deviation (1.329) which represents proximity of observations to the mean. The companies greatly ensured that there was strategic sourcing so as to ensure the goods were delivered in time. The companies also largely had effective demand management system as well as distribution management system. Finally, the companies largely ensured that the products were stored well by implementing effective warehouse planning.

\section{Management Commitment}

The study also sought information on the state of management commitment for the firms. Table VII shows results regarding management commitment as a total quality 
management factor. Various dimensions of the variable are considered and assessed.

\section{TABLE VII: MANAGEMENT COMMITMENT}

\begin{tabular}{|c|c|c|c|}
\hline & $\mathrm{N}$ & Mean & Std. Dev. \\
\hline $\begin{array}{l}\text { The company leadership is effective in } \\
\text { formulation and promotion of quality } \\
\text { policies. }\end{array}$ & 36 & 3.5278 & 1.34134 \\
\hline $\begin{array}{l}\text { The management of the firm pays } \\
\text { attention to quality planning as a facet of } \\
\text { TQM aimed at improving supply chain } \\
\text { performance. }\end{array}$ & 36 & 2.9722 & 1.29804 \\
\hline $\begin{array}{l}\text { The quality guidelines and policies of the } \\
\text { firm are constantly evaluated and } \\
\text { improved. }\end{array}$ & 36 & 3.4444 & 1.31897 \\
\hline $\begin{array}{l}\text { There is a well constituted and facilitated } \\
\text { quality standards team that closely } \\
\text { monitors implementation of quality } \\
\text { policies. }\end{array}$ & 36 & 3.5833 & 1.15573 \\
\hline $\begin{array}{l}\text { Fairy adequate level of resources are } \\
\text { availed to support quality initiatives. }\end{array}$ & 36 & 3.7778 & 1.19788 \\
\hline Average & & 3.4611 & 1.26239 \\
\hline
\end{tabular}

Management commitment as a means of total quality management was highly regarded by the firms. This was indicated by the mean of the means (3.4611) and low standard deviation (1.262) which sign posts proximity of observations to the mean. It was largely agreed that the companies' leadership were effective in formulation and promotion of quality policies. The firms were also found to have largely established well constituted and facilitated quality standards team to closely monitor the implementation of quality policies. In addition, the management were largely committed in resource provision and there was fairy adequate level of resources to support quality initiatives. Nonetheless, the management of the firms only paid moderate attention to quality planning as a facet of TQM aimed at improving supply chain performance. There was further moderately regular evaluation and improvement of quality guidelines and policies in the firms.

\section{E. Customer Focus}

This part provides details of customer focus as a total quality management practice in the manufacturing entities. Table VIII provides information on customer focus as a TQM variable. Various dimensions of customer focus are included in the assessment.

The mean of the means (3.5) show that the manufacturing companies had moderate consideration to customer focus as a total quality practice. This is affirmed by the low standard deviation (1.27) which shows that the observations are held close to the mean. The company's quality management system was largely anchored on an effective communication platform to ensure stakeholders are informed and guided. In addition, the design and production of the company's products was found to be largely guided by strictly implemented, customer oriented standards. The company also largely paid attention to her relationships with customers and regularly collected feedback and acted promptly on complaints. Nonetheless, results established that the companies only moderately gave special attention to client satisfaction and loyalty. The institution of a variety of customer oriented product packages to customers to quench diverse tastes was also found to be only moderately entrenched.
TABLE VIII: CUSTOMER FOCUS

\begin{tabular}{|c|c|c|c|}
\hline & $\mathrm{N}$ & Mean & Std. Dev \\
\hline $\begin{array}{l}\text { The company's quality management } \\
\text { system is anchored on an effective } \\
\text { communication platform to ensure } \\
\text { stakeholders are informed and guided. }\end{array}$ & 36 & 3.6389 & 1.31264 \\
\hline $\begin{array}{l}\text { The design and production of the } \\
\text { company's products are always guided by } \\
\text { strictly implemented, customer oriented } \\
\text { standards. }\end{array}$ & 36 & 3.6667 & 1.14642 \\
\hline $\begin{array}{l}\text { The company gives special attention to } \\
\text { client satisfaction and loyalty. }\end{array}$ & 36 & 3.3333 & 1.35225 \\
\hline $\begin{array}{l}\text { The company offers a variety of customer } \\
\text { oriented product packages to customers to } \\
\text { quench diverse tastes. }\end{array}$ & 36 & 3.4167 & 1.18019 \\
\hline $\begin{array}{l}\text { The company pays attention to her } \\
\text { relationships with customers and regularly } \\
\text { collects feedback and acts promptly on } \\
\text { complaints. }\end{array}$ & 36 & 3.5833 & 1.38099 \\
\hline Average & & $\begin{array}{c}3.5277 \\
8 \\
\end{array}$ & 1.27449 \\
\hline
\end{tabular}

\section{INFERENTIAL STATISTICS}

\section{A. Multiple Regression Analysis}

The multiple linear regression was key in guiding generalisations of the research findings to the study population. Table IX provides a summary of the statistical output of F test on ANOVA.

\section{TABLE IX: F TEST ON ANOVA}

\begin{tabular}{cccccccc}
\hline \multirow{2}{*}{ Model } & \multirow{2}{*}{$\begin{array}{c}\text { Sum of } \\
\text { Squares }\end{array}$} & Df & Mean Square & F & Sig. \\
\hline \multirow{2}{*}{1} & Regression & 4.682 & 4 & 1.171 & 0.458 & $0.011^{\mathrm{a}}$ \\
& Residual & 286.527 & 32 & 8.954 & & \\
& Total & 291.201 & 36 & & & \\
& & &
\end{tabular}

a. Predictors: (Constant), Strategic Quality Planning, Supplier Relations Management, Customer Focus, Management Commitment.

b. Dependent Variable: Supply Chain Performance

At 5\% level of significance, the Analysis of Variance (ANOVA) statistics gave evidence that the gradient of the regression line was different from zero. This is because the $P$ value (0.011) was less than 5\% level of significance. It was therefore observed that, at least one of the independent variables (Strategic Quality Planning, Supplier Relations Management, Customer Focus and Management Commitment) was a useful predictor of supply chain performance.

The regression model summary output of the regression analysis further showed the usefulness of the model in predicting supply chain performance. The output explains the proportion of variation in the dependent variable (supply chain performance) influenced by the independent variables (total quality management) under analysis. Table $\mathrm{X}$ gives a summary of the model summary statistics.

The Coefficient of Determination ( $\mathrm{R}$ Square) stood at 0765. This meant that $76.5 \%$ of variation in supply chain performance was influenced by variation in the independent variable that is total quality management practices and its constituent variables: Strategic Quality Planning, Supplier Relations Management, Customer Focus and Management Commitment. To that effect, only $23.50 \%$ of variation in supply chain performance was explained by other factors not included in the model. As such, it was concluded that at 
least one of TQM variables was a useful predictor of supply chain performance.

TABLE X: MODEL SUMMARY

\begin{tabular}{cccccc}
\hline Model & R & R Square & $\begin{array}{c}\text { Adjusted R } \\
\text { Square }\end{array}$ & $\begin{array}{c}\text { Std. Error of } \\
\text { the Estimate }\end{array}$ & $\begin{array}{c}\text { Durbin- } \\
\text { Watson }\end{array}$ \\
\hline 1 & $0.888^{\mathrm{a}}$ & 0.788 & 0.765 & 2.20001 & 1.810
\end{tabular}

a. Predictors: (Constant), Strategic Quality Planning, Supplier Relations Management, Customer Focus and Management Commitment.

b. Dependent Variable: Supply Chain Performance.

Lastly, the coefficients table embodies the highpoint of the regression analysis. It shows in an objective manner, the effect of each independent variable (Strategic Quality Planning, Supplier Relations Management, Customer Focus and Management Commitment) on the dependent variable (Supply Chain Performance) which fundamentally forms the basis of testing the research hypothesis. Table XI gives the regression coefficients.

\begin{tabular}{|c|c|c|c|c|c|c|}
\hline & \multirow[t]{2}{*}{ Model } & \multicolumn{2}{|c|}{$\begin{array}{c}\text { Unstandardized } \\
\text { Coefficients }\end{array}$} & \multirow{2}{*}{$\begin{array}{c}\begin{array}{c}\text { Standardized } \\
\text { Coefficients }\end{array} \\
\text { Beta }\end{array}$} & \multirow[t]{2}{*}{$\mathrm{T}$} & \multirow[t]{2}{*}{ Sig. } \\
\hline & & B & Std. Error & & & \\
\hline \multirow{5}{*}{1} & (Constant) & 9.043 & 0.500 & & 18.09 & 0.003 \\
\hline & $\begin{array}{c}\text { Strategic } \\
\text { Quality } \\
\text { Planning }\end{array}$ & 0.701 & 0.301 & 0.694 & 2.329 & 0.014 \\
\hline & $\begin{array}{c}\text { Supplier } \\
\text { Relations } \\
\text { Management }\end{array}$ & 0.830 & 0.536 & 0.799 & 1.549 & 0.005 \\
\hline & Customer Focus & 0.567 & 0.107 & 0.498 & 5.299 & 0.017 \\
\hline & $\begin{array}{l}\text { Management } \\
\text { Commitment }\end{array}$ & 0.489 & 0.394 & 0.398 & 1.241 & 0.004 \\
\hline
\end{tabular}

a. Dependent Variable: Supply Chain Performance.

The results of the multiple linear regression analysis show that all the independent variables; Strategic Quality Planning, Supplier Relations Management, Customer Focus and Management Commitment have a positive and significant effect on Supply Chain Performance. The results support past studies by Vanichchinchai and Igel (2011), Fouad, Hamed and Abdulwahhab (2015) and Masindet and Ogollah (2014) who found that TQM positively influences performance of the supply chain. The regression model for total quality management and supply chain performance was therefore developed as follows:

Supply Chain Performance $=9.043+0.701$ (Strategic Quality Planning) + 0.830 (Supplier Relations Management) + 0.567 (Customer Focus) + 0.489 (Management Commitment)

The coefficient for strategic quality planning (0.701) implies that a unit increase in implementation of strategic quality planning would lead to a 0.701 unit increase in supply chain performance. The effect is statistically significant because the associated P-Value (0.014) is less than 0.05 level of significance. Hence, the null hypothesis was rejected, and a conclusion made that strategic quality planning is a useful predictor of organisational performance. The results support Tan, $\mathrm{Ng}$, Phuah, Phuah and Tan (2014), Kamau et al. (2015) and Baraza (2015) who indicated that strategic quality planning influences supply chain performance.

The coefficient for supplier relations management (0.830) denotes a positive effect of the variable on supply chain performance. The effect is statistically significant since the associated p-value of 0.005 falls below the $5 \%$ or 0.05 level of significance. The implication is that a unit increase in supplier relations management would lead to a 0.830 unit increase in supply chain performance. Hence, the null hypothesis was rejected, and a conclusion made that supplier relations management is a statistically significant predictor of supply chain performance. The results agree with Kitheka (2015), Rajab (2015) and Talib, Rahman and Qureshi (2011) who indicated that supplier relations management positively impacts on supply chain performance.

The coefficient for focus customer focus (0.567) shows a positive effect of the factor on supply chain performance. The effect is statistically significant because the associated p-value of 0.017 is less than $5 \%$ or 0.05 level of significance. As such, a unit increase in customer focus would result to a 0.567 unit increase in supply chain performance. The null hypothesis was therefore rejected, and a conclusion made that customer focus is a statistically significant predictor of supply chain performance. The study findings agree with Tan et al., (2014, Sik Jeong and Hong (2017) and Masindet and Ogollah (2014) who established that customer focus positively affects supply chain performance.

The coefficient for management commitment (0.489) shows a positive effect of the factor on supply chain performance. As such, a unit increase in management commitment would lead to a 0.489 unit increase in supply chain performance. The effect is considered to have met the statistical significance threshold since the associated P-value of 0.004 is less than $5 \%$ or 0.05 level of significance. Hence, the null hypothesis was rejected, and a conclusion made that management commitment is a useful determinant of supply chain performance. The study results are consistent with Vanichchinchai and Igel (2011) and Fouad, Hamed and Abdulwahhab (2015) who concluded that management commitment plays a pivotal positive role to supply chain performance. In conclusion therefore, total quality management is a statistically significant predictor of supply chain performance.

\section{Conclusions of the Study}

According to the findings of the study total quality management plays a pivotal role in shaping supply chain performance. In this regard, the study concluded that the NSE listed manufacturing companies' supply chain performance was fairly good on all the dimensions of the SCOR Model namely: costs, asset management, reliability, flexibility and responsiveness. On supplier relations management, it was concluded that the factor positively influences supply chain performance. As such, enhancement of supplier relations would lead to an improvement in supply chain performance.

With regard to strategic quality planning the study concluded further that strategic quality planning positively 
influences supply chain performance. Enhancement of strategic quality planning would result to an enhancement of performance of the supply chain. Further since management commitment positively influences the performance of the supply chain performance, improvement of management commitment would lead to improvement of performance of the supply chain. A further conclusion is made, based on regression analysis results, that customer focus positively affects supply chain performance. As such, an improvement of customer focus would result to an improvement in supply chain performance.

The study recommends measures to improve on all dimensions of the supply chain efficiency and performance. As implementation of TQM initiatives was found to largely affect the supply chain, it is recommended that the manufacturing firms pursue measures to further their implementation. Although supplier relations management was deeply entrenched, there is need to further the framework of supplier engagement to quality initiatives which was found to be only moderately practiced. More regular supplier audit is also recommended to ensure compliance with set quality standards. Regarding strategic quality planning, it is recommended that companies pursue strategic sourcing options so as to ensure the goods were delivered on time.

The study recommends further improvement of customer relations management function to ensure timely and effective handling of customers concerns and feedback to suppliers. There was a well-built quality management system that allowed consistent and timely communication and feedback with clients. The study recommends that manufacturing companies improve on consideration of customer focus which was only moderately considered. The study recommends regular market research to effectively monitor and respond to new market needs as they arise.

\section{REFERENCES}

Anderson, J. C., Rungtusanatham, M., \& Schroeder, R. G. (1994). A theory of quality management underlying the Deming management method. Academy of Management Review, 19(3), 472-509.

Arndt, H. (2004). Supply Chain Management. Springer.

Baraza, W. J. (2015). Strategic Quality Management Initiatives and Performance of Mobile Communications Service Providers in Kenya (PhD Thesis). University of Nairobi.

Boaden, R., Harvey, G., Moxham, C., \& Proudlove, N. (2008). Quality improvement: Theory and practice. Retrieved from https://digital.library.adelaide.edu.au.

Bonstingl, J. J. (1992). Deming's fourteen points applied to companies and schools. Resource Guide for Total Quality Management in Texas Schools, Texas Association of School Administrators, Austin, TX.

Bowersox, D. J., Closs, D. J., \& Cooper, M. B. (2002). Supply chain logistics management (Vol. 2). McGraw-Hill New York, NY.

Boyd, L., \& Gupta, M. (2004). Constraints management: What is the theory? International Journal of Operations \& Production Management, 24(4), 350-371.

Bryman, A., \& Bell, E. (2015). Business research methods. Retrieved from https://books.google.com.

Bulmberg, B., Cooper, D. R., \& Schindler, P. S. (2011). Business research methods. McGraw-Hill/Irwin, Boston.

Burt, D., Dobler, D., \& Starling, S. (2003). World Supply Chain Management: The Key to Supply Chain Management. McGraw-Hill Irwin, New York.

Cagnazzo, L., Taticchi, P., \& Brun, A. (2010). The role of performance measurement systems to support quality improvement initiatives at supply chain level. International Journal of Productivity and Performance Management, 59(2), 163-185.

Cai, J., Liu, X., Xiao, Z., \& Liu, J. (2009). Improving supply chain performance management: A systematic approach to analyzing iterative KPI accomplishment. Decision Support Systems, 46(2), 512521.

Carapeto, M., \& Holt, W. (2003). Testing for heteroscedasticity in regression models. Journal of Applied Statistics, 30(1), 13-20.

Casadesús, M., \& de Castro, R. (2005). How improving quality improves supply chain management: Empirical study. The TQM Magazine, 17(4), 345-357.

Chan, F. T., \& Qi, H. J. (2003). An innovative performance measurement method for supply chain management. Supply Chain Management: An International Journal, 8(3), 209-223.

Chang, G. (2009). Total quality management in supply chain. International Business Research, 2(2), 82.

Chen, I. J., \& Paulraj, A. (2004). Towards a theory of supply chain management: The constructs and measurements. Journal of Operations Management, 22(2), 119-150.

Christopher, M. (2016). Logistics \& supply chain management. Pearson UK.

Crainer, S., \& Dearlove, D. (2004). The quality revolution. Financial Times Handbook of Management, 290.

Dahlgaard, J. J., Khanji, G. K., \& Kristensen, K. (2008). Fundamentals of total quality management. Retrieved from https://books.google.com.

Dale, B. (2015). Total quality management. Retrieved from http://onlinelibrary.wiley.com.

Deming, W. E. (1986). Out of Crisis, Centre for Advanced Engineering Study. Massachusetts Institute of Technology, Cambridge, MA.

Durbin, J., \& Watson, G. S. (1971). Testing for serial correlation in least squares regression. III. Biometrika, 58(1), 1-19.

Easterby, M., Thorpe, R., \& Jackson, P. R. (2012). Management research. Retrieved from https://books.google.com.

Eriksson, P., \& Kovalainen, A. (2015). Qualitative methods in business research: A practical guide to social research. Retrieved from https://books.google.com.

Estampe, D., Lamouri, S., Paris, J.-L., \& Brahim-Djelloul, S. (2013). A framework for analysing supply chain performance evaluation models. International Journal of Production Economics, 142(2), 247258.

Evans, James R., \& Dean, J. W. (2003). Total quality: Management, organization, and strategy. Retrieved from http://library.wur.nl/WebQuery/clc/1727366.

Evans, James Robert, \& Lindsay, W. M. (2002). The management and control of quality (Vol. 5). Retrieved from http://tocs.ulb.tudarmstadt.de/179836862.pdf.

Farooq, M. S., Akhtar, M. S., Ullah, S. Z., \& Memon, R. A. (2007). Application of Total Quality Management in Education. Online Submission, 3(2), 87-97.

Flynn*, B. B., \& Flynn, E. J. (2005). Synergies between supply chain management and quality management: Emerging implications. International Journal of Production Research, 43(16), 3421-3436.

Forker, L. B., Mendez, D., \& Hershauer, J. C. (1997). Total quality management in the supply chain: What is its impact on performance? International Journal of Production Research, 35(6), 1681-1702.

Fouad, R. H., Hamed, Z. M., \& Abdulwahhab, O. A. (2015). Exploring TQM and SCM Practices Influence on Oil Pipelines Company's Performance. International Review of Management and Business Research, 4(4 Part 1), 1070.

Garetti, M., \& Taisch, M. (2012). Sustainable manufacturing: Trends and research challenges. Production Planning \& Control, 23(2-3), 83104.

Gliem, J. A., \& Gliem, R. R. (2003). Calculating, interpreting, and reporting Cronbach's alpha reliability coefficient for Likert-type scales. $\quad$ Retrieved from https://scholarworks.iupui.edu/handle/1805/344.

Goetsch, D. L., \& Davis, S. (2006). Quality management: Introduction to total quality management for production, processing, and services. Prentice Hall.

Goetsch, D. L., \& Davis, S. B. (2014). Quality management for organizational excellence. Retrieved from http://abufara.com/abufara.net/images/abook_file/back/Ch1.pdf.

Goldratt, E. M. (1990). Theory of constraints (TOC). Croton-on-Hudson, NY, USA: North River Press.

Gunasekaran, A., Patel, C., \& McGaughey, R. E. (2004). A framework for supply chain performance measurement. International Journal of Production Economics, 87(3), 333-347.

Gupta, A., Bhardwaj, A., \& Kanda, A. (2010). Fundamental concepts of theory of constraints: An emerging philosophy. World Academy of Science, Engineering and Technology, 46, 686-692.

Harrison, A., \& Van Hoek, R. I. (2008). Logistics management and strategy: Competing through the supply chain. Pearson Education.

Hashmi, K. (2007). Introduction and implementation of total quality 
management (TQM). Journal of Electronics and Quality Management, 6(1), 45-57.

Hausman, W. H. (2004). Supply chain performance metrics. In The practice of supply chain management: Where theory and application converge (pp. 61-73). Springer.

Hervani, A. A., Helms, M. M., \& Sarkis, J. (2005). Performance measurement for green supply chain management. Benchmarking: An International Journal, 12(4), 330-353.

Hugos, M. H. (2011). Essentials of supply chain management (Vol. 62). John Wiley \& Sons.

José, T., Juan. (2005). Components of successful total quality management. The TQM Magazine, 17(2), 182-194.

Kamau, P. M., Wanjiku, P. W., Langat, L. C., Lijembe, M. T., Majaha, C., Ojwang, P. O., Makunyi, P. M. (2015). Supply chain quality planning and performance of water bottling companies in Nairobi city county, Kenya.

Katua, P. A. (2014). The Impact of Supply Integration on the Supply Chain Performance in the Manufacturing Firms in Kenya ( $\mathrm{PhD}$ Thesis). School of Business, University of Nairobi.

Kelly, T. F. (2013). Fourteen More Points: Successful Applications of Deming's System Theory. American Journal of Management, 13(2), 36.

Kitheka, S. (2015). The Effect of Supplier Quality Management on Organizational Performance: A Survey of Supermarkets in Kakamega Town.

Kothari, C. R. (2011). Research methodology: Methods and techniques. Retrieved $\mathrm{http} / / /$ books.google.com/books?hl=en $\& \mathrm{lr}=\& \mathrm{id}=8 \mathrm{c} 6 \mathrm{gkbKi}-$ F4C\&oi=fnd\&pg=PR7\&dq=Kothari, $+(2004) \&$ ots $=$ iHhBnQU8nL\&si $\mathrm{g}=$ Dw-XCoat-i7yHF2szK-fo7y3394.

Krauss, S. E. (2005). Research paradigms and meaning making: A primer. The Qualitative Report, 10(4), 758-770.

Kuei, C.-H., Madu, C. N., \& Lin, C. (2001). The relationship between supply chain quality management practices and organizational performance. International Journal of Quality \& Reliability Management, 18(8), 864-872.

Kutner, M. H., Nachtsheim, C., \& Neter, J. (2004). Applied linear regression models. McGraw-Hill/Irwin.

Li, L., Su, Q., \& Chen, X. (2011). Ensuring supply chain quality performance through applying the SCOR model. International Journal of Production Research, 49(1), 33-57.

Long, J. S., \& Ervin, L. H. (2000). Using heteroscedasticity consistent standard errors in the linear regression model. The American Statistician, 54(3), 217-224.

Mackenzie, N., \& Knipe, S. (2006). Research dilemmas: Paradigms, methods and methodology. Issues in Educational Research, 16(2), 193-205.

Masindet, E., \& Ogollah, K. (2014). Influence of Total Quality Management Practices on Supply Chain Performance of Cement Manufacturing Firms in Kenya. European Journal of Business Management, 1(11), 181-197.

Mohideen, O., \& Vijayavel, J. (2014). Principles of Total Quality Management $\quad$ (TQM). $\quad$ Retrieved http://ijpsbm.com/docs/papers/september2014/V2I905.pdf.

Montgomery, D. C., Peck, E. A., \& Vining, G. G. (2015). Introduction to linear regression analysis. John Wiley \& Sons.

Mugenda, O. M., \& Mugenda, A. G. (2003). Research methods. Nairobi: ACTS.

Ngui, D. M. (2008). On the Efficiency of the Kenyan Manufacturing Sector: An Empirical Analysis. Shaker.

Njoroge, M., George. (2014). Impact of supply chain management risks and challenges on performance of food manufacturing firms in greater Nairobi, Kenya. (PhD Thesis). School of Business, University of Nairobi.

Oketch, C. S., Chirchir, M., \& Kinyua, S. (2014). Supply chain performance and performance of manufacturing pharmaceutical firms in Kenya.

Oso, W. Y., \& Onen, D. (2005). A Guide to writing Research Proposals and Reports. Kisumu: Option Press.

Ott, R. L., \& Longnecker, M. (2015). An introduction to statistical methods and data analysis. Nelson Education.

Otto, A., \& Kotzab, H. (2003). Does supply chain management really pay? Six perspectives to measure the performance of managing a supply chain. European Journal of Operational Research, 144(2), 306-320.

Ou, C. S., Liu, F. C., Hung, Y. C., \& Yen, D. C. (2010). A structural model of supply chain management on firm performance. International Journal of Operations \& Production Management, 30(5), 526-545.

Poluha, R. G. (2007). Application of the SCOR model in supply chain management. Cambria Press.

Rajab, F. A. (2015). Quality management practices and supply chain performance of large scale manufacturing firms in Kenya. ( $\mathrm{PhD}$ Thesis). UNIVERSITY OF NAIROBI.

Rampersad, H. K., \& Narasimhan, K. (2005). Managing total quality: Enhancing personal and company value. Tata McGraw-Hill.

Shapiro, S. S., \& Wilk, M. B. (1965). An analysis of variance test for normality (complete samples). Biometrika, 591-611.

Sik Jeong, J., \& Hong, P. (2017). Customer orientation and performance outcomes in supply chain management. Journal of Enterprise Information Management, 20(5), 578-594.

Stadtler, H. (2005). Supply chain management and advanced planningBasics, overview and challenges. European Journal of Operational Research, 163(3), 575-588.

Stephens, S. (2001). Supply chain council \& supply chain operations reference (scor) model overview. Version.

Supply Chain Council. (2008). SCOR-Supply Chain Operations Reference Model Version 9.0. Supply Chain Council, Cypress.

Talavera, G. (2010). Measuring supply chain performance in selected Philippine manufacturing companies. Philippine Management Review, $17,52-65$.

Talib, F., Rahman, Z., \& Qureshi, M. N. (2011). A study of total quality management and supply chain management practices. International Journal of Productivity and Performance Management, 60(3), 268288.

Tan, K. K. S., Ng, H. P., Phuah, W. H., Phuah, Y. Y., \& Tan, C. W. (2014). Total quality management on supply chain management: A study on logistics companies in Malaysia (PhD Thesis). UTAR.

Tavakol, M., \& Dennick, R. (2011). Making sense of Cronbach's alpha. International Journal of Medical Education, 2, 53.

Tayur, S., Ganeshan, R., \& Magazine, M. (2012). Quantitative models for supply chain management (Vol. 17). Springer Science \& Business Media.

Tsay, R. S. (2005). Analysis of financial time series (Vol. 543). Retrieved from

https://books.google.com/books?hl=en\&lr=\&id=ddL4tTLb 08C\&oi= fnd\&pg $=$ PR7\&dq=test+for+auto+correlation+in+regression+analysis \&ots=bwvsJ5Pj3a\&sig=Y-C7Q3Qd9ot2tiGjVM9icHNtdtM.

Tulasi, C. L., \& Rao, A. R. (2012). Review on theory of constraints. International Journal of Advances in Engineering \& Technology, 3(1), 334.

Vanagas, P., \& Žirgutienė, S. (2015). TQM Paradigm Shift in The Context of Change Management. Engineering Economics, 43(3), 15-21.

Vanichchinchai, A., \& Igel, B. (2011). The impact of total quality management on supply chain management and firm's supply performance. International Journal of Production Research, 49(11), 3405-3424.

Wagner, S. M., \& Bode, C. (2008). An empirical examination of supply chain performance along several dimensions of risk. Journal of Business Logistics, 29(1), 307-325.

Yazici, B., \& Yolacan, S. (2007). A comparison of various tests of normality. Journal of Statistical Computation and Simulation, 77(2), $175-183$.

Yong, J., \& Wilkinson, A. (2001). Rethinking total quality management. Total Quality Management, 12(2), 247-258. 